Sylwester Jędrzejewski SDB

\title{
Koncepcje mesjańskie judaizmu po deportacji babilońskiej
}

Mesjanizm Izraela, oparty głównie o obietnicę trwałości dynastii Dawida (2 Sm 7), łączy się w tekstach apokaliptycznych okresu deportacji i podeportacyjnym, zwłaszcza w okresie II Świątyni - zarówno w tych biblijnych, jak i apokryficznych - z eschatologią. Królewski Mesjasz jest w nich związany z tęskną myślą nacjonalistycznych idealistów o tryumfie czasów ostatecznych, o uwolnieniu Izraela od ucisku innych nacji, o założeniu nowego królestwa Izraela. Nie był więc Mesjasz, jak się wydaje, głównym przedmiotem nadziei Izraela. Był raczej środkiem do spełnienia się tej idei, którą Nowy Testament wyraża poprzez istotną treść przepowiadania Jezusa, rekapitulującą historię zbawienia: „Przybliżyło się do was królestwo Boże” (Łk 10, 9; Mk 1, 15). W ten sposób kształtują się też dwa podstawowe typy mesjanizmu: historyczno-narodowy oraz eschatologiczno-apokaliptyczny, jakkolwiek często z sobą ściśle złączone. Wiąże je nierzadko wspólna idea króla mesjańskiego królestwa, choć też różnie pojmowanego. Postać Mesjasza w tradycyjnych koncepcjach mesjańskich jawi się w funkcji pasterza i króla. Pojawiają się jednak w okresie podeportacyjnym również nowe idee mesjanizmu, prezentujące Mesjasza w funkcji kapłańskiej i w funkcji Syna Człowieczego, specyficznie eschatologicznego monarchy bądź Syna Bożego.

Mesjańskie poglądy okresu deportacji babilońskiej i czasu judaizmu II Świątyni, aczkolwiek dość zróżnicowane, cechowało przekonanie, że szczytem czasu jest mesjańskie królestwo. Nie ma być ono jednak jakąś ponadczasową ideą, lecz jednorazowym, decydującym wydarzeniem historycznym; aktem, który nastąpi w określonym czasie, przestrzeni, kształcie i miejscu i będzie dziełem mesjańskiego króla ${ }^{1}$.

${ }^{1}$ J. BRIGHT, Historia Izraela, Warszawa 1994, s. 472. 


\section{Mesjasz - Pasterz}

Pierwszym typem mesjańskim realizującym królestwo Boga jest Mesjasz sprawujący funkcje pasterza. Określenie „Mesjasz” wskazuje tutaj na funkcję wypełnianą przez króla bądź pasterza. W starszych niż izraelska religiach ościennych, głównie opartych o mitologię, odnajdujemy bóstwa występujące w funkcji pasterzy. W mitologii sumeryjsko-babilońskiej oraz akkadyjskiej widoczny jest bóg-pasterz Dammuzi oraz An (Anun), sumeryjski bóg nieba nazywany pasterzem całego świata ${ }^{2}$. Marduk akkadyjski zwany był z kolei pasterzem ludzkości ${ }^{3}$. Podobnie królowie (np. Hammurabi) przedstawiani są jako dobrzy pasterze ludzi ${ }^{4}$. W Egipcie tytuł pasterza używany był powszechnie w odniesieniu do bóstw, ale i często pokazywał króla jako czuwającego pasterza. Tak więc w Izraelu obecność metaforycznej idei pasterza nie odbiegała u swych początków od takiej idei w kulturowo bliskiej rzeczywistości Orientu. Dawid np. ukazany jest jako król, ale przydaje mu się także atrybut pasterza: „I ustanowię nad nimi jednego pasterza, który je będzie pasł, mego sługę, Dawida. On je będzie pasł, on będzie ich pasterzem” (Ez 34, 23; por. 37, 24)5. Między „królem” a „pasterzem” istnieje więc istotna więź. Nawet berło, atrybut króla, wywodzi się od pasterskiej laski, a oznacza nie tylko znak władzy sprawowanej z moca pochodzącą od Boga, ale jest także symbolem powinności obrony $(\mathrm{Lb} 21,18)^{6}$. Dość powszechnie, nie tylko w Izraelu, władców uważano za pasterzy swoich narodów, troszczących się o dobro powierzonej im trzody. Przede wszystkim pasterzem jest jednak sam Jahwe (Syr 18, 13; Iz 40, 11; Jr 31, 10; Ez 34, 12), który objawia siebie jako pasterza troszczącego się o swój lud przez nowego Dawida - pasterza (Ez 34, 23-24). Mesjasz ma być więc odblaskiem Jahwe, tym, który w imieniu Boga wypełni Jego zamiary. O Mesjaszu-pasterzu traktuje Za 11, 4-17. Bóg posyła swojemu ludowi dobrego pasterza, który ma uchronić go przed działaniami złych pasterzy. Tenże pasterz zostanie uderzony mieczem. Zawarta jest tutaj idea bardzo podobna do mesjańskiej postaci Sługi z orędzia Izajasza ${ }^{7}$.

Typem mesjasza jest także Cyrus (Iz 44, 28). Co prawda jest faktem zupełnie odosobnionym, aby mesjasza upatrywano poza Izraelem, ale w tekście

${ }^{2}$ C. Schedl, Historia Starego Testamentu, t. 1, Tuchów 1996, s. 6.

${ }^{3}$ R. Rumianek, Obraz pasterza na Starożytnym Wschodzie $i w$ Biblii, „Studia Theologica Varsaviensia" 19 (1981) nr 1, s. 7.

${ }^{4}$ A. Mierzejewski, Tajemnice glinianych tabliczek, Warszawa 1963, s. 161.

${ }^{5}$ J. HoMErski, Pasterz czasów mesjańskich, [w:] Mesjasz w biblijnej historii zbawienia, red. S. Łach, M. Filipiak, Lublin 1974, s. 145.

${ }^{6}$ E. LipIŃsKI, Berger, pasteur, [w:] Dictionnaire encyclopedique de la Bible, red. P.-M. Bogaert, Brepols 1987, s. 199.

7 T. Brzegowy, Mesjanizm Deutero-Zachariasza, „Analecta Cracoviensia” 27 (1995), s. 100. 
Izajasza jest on określony jako „pasterz”, który spełni wszystkie pragnienia Jahwe. Widać więc z tego, że w okresie po zburzeniu świątyni w 586 roku zmienia się koncepcja wybawienia, z którą bezpośrednio związane jest określenie „pasterz”. Wydaje się, że należy mówić tu o uniwersalizacji panowania Jahwe, który bierze sobie jako swego sługę każdego, kogo zechce, aby był Jego narzędziem. Cyrus może być namaszczonym pasterzem, ponieważ to Jahwe jest właściwym odkupicielem Izraela, jak świadczy o tym tekst Iz 44, 24 i Ez $34^{8}$. Byłoby to zgodne z profetycznym tekstem Jeremiasza, który odnosząc się do wybawienia z niewoli, mówi o pasterzach według „serca Bożego”, bez odniesień do Dawida (Jr 3, 15). Ponieważ termin g'l (odkupiciel) jest używany w różnych tekstach biblijnych nade wszystko w kontekście wybawienia z niewoli, stąd można przypuszczać, że Cyrusa widzi się jako współdziałającego z wybawiającym Bogiem (por. Iz 51, 5. 11), na wzór Mojżesza. Ponadto Iz 63, 11 wyraźnie mówi o Mojżeszu-pasterzu, którego Jahwe wydobył z wody. Zależność idei pasterza-Cyrusa i pasterza-Mojżesza wydaje się tutaj oczywista. Trudno jest jednak przypuścić, aby wystąpiło tutaj odniesienie do pasterzaDawida (por. Ez 34, 23-24), jako że z tym ostatnim związana jest w Starym Testamencie nieodłącznie idea królewskiego pasterza-Mesjasza wyłącznie dla Izraela z podkreśleniem ciągłości rodu Dawida. Tak więc idea mesjańska, jeśli w ogóle o takowej mówić tutaj można, w tym przypadku ograniczałaby się do posłuszeństwa - nawet nieświadomego - Bogu, który realizuje swój plan poprzez wybrane, czyli namaszczone osoby.

\section{Mesjasz - Król}

Mesjasz prezentowany w okresie II Świątyni nosi też pewne cechy królewskie, głęboko jednak ograniczające Go do nacji żydowskiej, zwłaszcza w akcentowaniu jego związku z Dawidem. To typowy pogląd religijnej, ukierunkowanej jednak nacjonalnie grupy Izraela, która wierzyła głęboko w swoje wybraństwo ${ }^{9}$. Nadzieje mesjańskie są tak pełne niecierpliwości, że ich zrealizowanie oczekiwane jest natychmiast i wiąże się z intronizacją Mesjasza w Jerozolimie, po uwolnieniu judaizmu od pogan. Pogląd ten charakterystyczny jest dla mesjanizmu typu królewskiego, ujmowanego w kategoriach historycznej eschatologii realistycznej, bliskiej spełnienia. Jednakże w późnym okresie II Świątyni, postać Mesjasza znajduje się jakby w dalekim tle, jakkolwiek intensyfikują się oczekiwania wyzwolenia. Akcent jednak nie pada na zbawczą rolę przyszłego Mesjasza. A więc zmienia się dotychczasowy, bardzo związany

${ }^{8}$ J. W. RosŁon, Mesjasz dawca życia, [w:] Mesjasz w biblijnej..., dz. cyt., s. 293.

${ }^{9}$ R. E. Brown, Zarys teologii Starego Testamentu, [w:] Katolicki komentarz biblijny, red. R. E. Brown, J. A. Fitzmyer, R. E. Murphy, Warszawa 2001, s. 2029. 
z wcześniejszymi tekstami biblijnymi, pogląd na rolę i znaczenie zbawczo-uwalniającego Mesjasza. W tym czasie można mówić raczej nie tyle o „Mesjaszu”, ile o „mesjanizmie”. Istotne jest przy tym historyczne tło późnego okresu II Świątyni, w którym nabiera znaczenia i intensywnie rozwija się apokaliptyka. Gorzkie doświadczenia sprawiły, że świat cały począł jawić się jako zły, a szczególne zło dotknęło naród przymierza, który miał przecież cieszyć się opieką Boga. Prawo do własnej interpretacji owych obietnic, do koncentracji na samym sobie staje się dominujące i wyraża się w postaci aspiracji narodowych i eschatologicznych jednocześnie. Spełnienie przymierza z Dawidem odczytywane było poprzez relację do świetlanego czasu panowania Salomona, a to nadawało temu zjawisku wymiar polityczny. Jeremiasz daje wyraz historycznego, o charakterze królewskim, pojmowania władzy Mesjasza przez spełnianie prawa i sprawiedliwości „na ziemi” (Jr 23, 5-6; 33, 15). Również Ezechiel w sposób wyraźny daje podstawy do rozumienia przyszłego Mesjasza Dawidowego jako króla kraju, który Jahwe dał słudze swemu Jakubowi, określając tym samym niemal geograficzne granice jego władzy (Ez 37, 24-25). Zasadnicza grupa żydowska okresu II Świątyni, w miarę upływu czasu, coraz bardziej skłaniała się ku takiej właśnie koncepcji ziemskiego króla, w ramach ruchów mesjanistycznych. Naród żydowski, pozbawiony politycznej wolności oczekiwał, że przyszły Mesjasz, wprowadziwszy Boże panowanie, odrestauruje także widzialne, wielkie królestwo Dawida i Salomona, cieszące się wolnością i pokojem. Oczekiwanie na Mesjasza, podsycane żydowskim, wybrańczym nacjonalizmem sprzyjało wizji Mesjasza - władcy królestwa ziemskiego. Sam termin $m \bar{a} \breve{s}_{s}{ }^{a} h$ wiąże się przecież z namaszczeniem, a to odnosiło się w przeważającej mierze do obrzędu inwestytury królewskiej. Liczne ruchy mesjańskie, zwłaszcza te bliskie czasowi Jezusa, korzystały z prototypicznych, biblijnych postaci królów - wodzów swego narodu. Okres międzytestamentalny, a więc łączący w sobie schyłek objawienia Starego Testamentu, wespół z tworzącym się chrześcijaństwem, staje się tłem intensywnego rozwoju różnych poglądów mesjańskich. Osoba nosząca cechy Mesjasza jest często traktowana w nich tak samo, jak dawni królowie Izraela, a jej przyszłe panowanie pozostaje w ramach instytucji teokratycznych. Apokryfy jednak, podobnie jak pisma organizacyjne wspólnoty z Qumran, rozróżniają płaszczyznę sakralno-kultyczną od królewskiej. Tak np. Księga Jubileuszów element kultyczny przypisuje Lewiemu, zaś władzę rezerwuje dla Judy (Jub 31, 13-22). Podobny pogląd zawierają schrystianizowane, pierwotnie żydowskie Testamenty 12 Patriarchów. Ten sposób myślenia widoczny jest zatem w socjologicznie i doktrynalnie zróżnicowanych środowiskach żydowskich. Nawet chrystologia nowotestamentowa sięga do tego typu argumentacji, choćby przez używanie wprost bądź daleko idące zapożyczenia Ps 2 i Ps 110, kiedy kreśli postać Jezusa w ramach teologii królewskiego Dawida. Odbiega od 
tej charakterystyki jedynie postać ,jakby mesjańska” z Jub 31, 18-2010: „Bądź księciem, ty i jeden z twoich synów dla synów Jakuba; [...] W dniu, w którym usiądziesz na tronie prawdziwym i chwalebnym, nastąpi wielki pokój ${ }^{11}$ dla całego potomstwa ukochanych synów". Ta postać królewska, syn Jakuba, nie kultywuje linii Dawidowej. Odniesienie do Jakuba zdaje się ogarniać cały naród Izraela i wyraża najogólniejszą koncepcję mesjanizmu królewskiego.

\section{Mesjasz - Syn Człowieczy}

Mesjanizm innego typu związany jest natomiast przemożnie z biblijną postacią Syna Człowieczego, obecną u Ezechiela, zaczerpniętą bezpośrednio przez literaturę apokryficzną i Nowy Testament z Dn 7. Jest to widoczne w tekstach typowo eschatologicznych, choć ujętych w konwencji apokaliptycznej. Szczególne znaczenie ma tutaj doktryna Deutero-Zachariasza (Za 9-14), albowiem przedstawia przyszłego Mesjasza w kategoriach zarówno apokaliptycznych, jak i eschatologicznych. Era mesjańska nadejdzie jako realizacja woli Jahwe pokonującego wroga, a jednocześnie oczyszczającego swój lud poprzez próbę wierności. Owa era rozpocznie się objęciem przez Mesjasza w swoje posiadanie Syjonu, miejsca promieniowania pokoju (Za 9, 9-10). Taki mesjanizm królewski prezentuje się tutaj jednak radykalnie odmiennie od typowego mesjanizmu starotestamentowego oraz mesjanizmu obecnego w apokryficznych utworach apokaliptycznych. Wypowiedź Zach 9, 9-10 mówiąca o „królu” przychodzącym na Syjon wskazuje na Mesjasza królewskiego, ale jest to król pokorny. Nawet Syn Człowieczy z Dn 7, 13-14, tekstu przecież apokaliptycznego, nie wydaje się posiadać cech zwycięskiego króla, dającego wolność o charakterze politycznym. Tajemnicze rysy Syna Człowieczego predysponują Go do bycia Mesjaszem transcendentnym, bardzo blisko związanym z Bogiem, o cechach łączących kondycję ludzką z wielkością Boga. Co najwyżej świadczyć to może o połączeniu „nieba z ziemią" jako odsłonie Bożej odpowiedzi na żywą tęsknotę Ludu Bożego za ziemską rzeczywistością mającą cechy idealnej, trwałej nieprzemijalności. Takie myślenie nieco zakłóca przeciwstawienie w Dn 7 Syna Człowieczego bestii, która zdaje się reprezentować ziemskie potęgi polityczne. Postać Mesjasza-Syna Człowieczego jawi się jako element łączący królestwo - potęgę ziemską z królestwem, które ma ustanowić Bóg. Obraz więc zdaje się być gatunkowo apokaliptyczny, niemniej jednak w ten sposób autor utożsamia

${ }^{10}$ Pismo o cechach apokaliptycznych z połowy II w. przed Chr.; zob. O. S. Wintermute, The Old Testament Pseudepigrapha, red. J. H. Charlesworth, New York 1983, t. 2, s. 46.

${ }^{11}$ A. Diez Macho, Apocrifos del Antiquo Testamento, Madrid 1984, t. 1, 154, thumaczy: „wielkie zbawienie”. 
się w pewien sposób z mesjanizmem narodowym. Nie przestaje być zatem synem swego narodu, choć zdaje się nie podzielać naiwnego idealizmu środowisk nacjonalistycznych. Właściwe jest to dla apokaliptyki, która szuka uzasadnienia dla zrozumienia swego czasu w biblijnej przeszłości, pewien sobie właściwy idealizm rzutując w mającą się cechować trwałością przyszłość. Myślenie apokaliptyczne jest bowiem myśleniem historycznym, zanurzonym w dziedzictwie starotestamentowym, głęboko wnikającym w Słowo Boże, które przenosi w eschatologiczne realia pozahistoryczne, transcendując obecną rzeczywistośćc ${ }^{12}$. Dlatego eschatologiczny Mesjasz, jakkolwiek historyczny, ma dokonać nie tyle odnowienia i naprawienia istniejącej rzeczywistości, ile raczej jawi się Jego nadejście w formie katastroficznej interwencji Boga tworzącego nową rzeczywistość i nowy porządek. Być może dzieje się tak z inspiracji biblijnych proroków zapowiadających ową nowość (Iz 42, 9; 43, 19; 65, 17; 66, 22; Jr 3, 16), w sposób szczególny w kształcie nowego przymierza (Jr 31, 31; Ez 11, 19; 36, 26), w perspektywie nowego nieba i nowej ziemi (Iz 51, 6). Postać Mesjasza w ten sposób wskazuje na Jego główny przymiot, jakim jest głęboki związek z Bogiem, albowiem to Bóg sam zapowiada i tworzy ową nową rzeczywistość. Jeśli w żydowskiej apokaliptyce Mesjasz prezentowany jest jako wybrany przez Boga, nieomal syn Boga, który skupia w sobie całą moc Boga dla przewodzenia „świętej wojnie", to tutaj Syn Człowieczy jest jednak kimś wyraźnie różnym od Boga, albowiem on sam staje przed Bogiem i otrzymuje od Niego królestwo. Jako indywiduum nie jest więc tylko ideą ani symbolem, ponieważ już prorocy przeddeportacyjni zawsze wiązali przyszłe królestwo z Mesjaszem-osobą (Iz 7; 11; Mich 5). Osoba ta jednak przekracza nacjonalizm ówczesnego Izraela i przyjmuje rysy uniwersalne, najpełniej w postaci wiecznego panowania nad wszystkimi narodami, w uniwersalnym królestwie.

\section{Mesjasz - Wybrany Sprawiedliwy}

Podobną dystynkcję odrębności posiada Mesjasz w rozumieniu środowiska judaistycznego, które stworzyło Księgę Przypowieści Henet, u kresu I w. przed Chr. ${ }^{13}$ Syn Człowieczy, wyraźnie różny od Pana Duchów - Głowy Dni (Boga), nosi tu określenie „Mesjasz” (Henet 47) bądź „Wybrany” (Henet 49, 2). Niewątpliwie pismo to kontynuuje tradycję zaczerpniętą z Dn 7, 13, ale Syn Człowieczy-Mesjasz posiada przymiot preegzystencji: „I z tego powodu

${ }^{12}$ R. Rubinkiewicz, Apokaliptyka u progu ery chrześcijańskiej, „Ruch Biblijny i Liturgiczny" 1 (1998), s. 57.

${ }^{13}$ L. Fusella, Libro di Enoc (Enoc etiopico), [w:] Apocrifi dell'Antico Testamento, red. P. Sacchi, Torino 1997, t. 1, s. 23-30. 
został on wybrany i ukryty przed nim, zanim świat został stworzony i na wieki” (Henet 48, 6); „Zanim słońce i konstelacje zostały stworzone, zanim gwiazdy nieba zostały utworzone, jego imię zostało nazwane przed Panem Duchów” (Henet 48, 3); „Albowiem od początku Syn Człowieczy był ukryty i Najwyższy zachował go przed swą mocą i objawił go [tylko] wybranym" (Henet 62, 7) ${ }^{14}$. Ale ciekawe jest to, że już został on objawiony „Świętym i sprawiedliwym” i „ustrzegł on los sprawiedliwych” (Henet 48, 7). Mesjasz więc już wypełnił jakieś zadanie zlecone mu przez Boga. Zapewne, tak jak w rozumieniu biblijnym, chodzi tutaj o związek Mesjasza z grupą socjalno-religijną, której podstawowym atrybutem jest wierne zachowywanie Przymierza. Grupa ta, podkreślająca swoją odrębność i wyraźnie dystansująca się od judaizmu świątynnego, prezentuje zatem własne widzenie Mesjasza. Z jednej strony jest to Mesjasz, który już działa w stosunku do pewnej grupy Izraela, z drugiej zaś ma to być Mesjasz eschatologiczny. Mesjasz, zwany też „Wybranym”, stoi ciągle przed Bogiem, a jego chwała i moc po wieki wieków (Henet 49, 2). Jest to więc jakby stan permanentnego zanurzenia w Bogu, a nie tożsamości z Nim. Ich bliskość zdaje się płynąć z interpretacji Iz 11, 2: „I w nim mieszka duch mądrości i duch, który daje zrozumienie i duch wiedzy i mocy i duch tych, którzy śpią w sprawiedliwości” (Henet 49, 3). Równie enigmatycznie wyraża się o owej jedności poprzez termin „Wybrany” Apokalipsa Abrahama 31, 1 mówiąc o Wybranym przez Boga. Sądzić można, że działanie owego Mesjasza ujawni się w czasie, który Stary Testament określa mianem „Jom Jahwe”. Wskazuje na to określenie: „dzień ich ucisku i niepokoju”, w którym nie dostąpią zbawienia królowie ziemi. Zatem pojmowanie „Dnia Jahwe” nosi cechy eschatologii. Ale czy jest to eschatologia transcendentna i uniwersalna, czy raczej historyczna i ograniczona? Henet jest tekstem apokaliptycznym, zatem sądzić należy, iż relacjonuje przekonanie o historycznie realistycznej, przyszłej interwencji Boga, lokowanej w eschatologii, która posiada tutaj cechy absolutystyczne. Ponieważ mowa jest o pokucie niektórych, począwszy od „owego dnia” (Dnia Pańskiego), sądzić można, że chodzi tu o eschatologię historyczną, wydarzenie w niesprecyzowanym co prawda, ale konkretnym czasie, miejscu i rzeczywistości ziemskiej. Przesądza rzecz, jak się wydaje, bezpośrednie utożsamienie „owego dnia” z zaistnieniem (nowego?) przymierza: „ten dzień został przygotowany, dla wybranych [będzie to] przymierze...” (Henet 60, 6). Ponadto Syn Człowieczy jest identyczny ze sprawiedliwością, co pokazuje go jako będącego istotą, zasadą i sensem przymierza: „To jest

${ }^{14}$ Teksty Henet za R. Rubinkiewicz, Księga Henocha etiopska, [w:] Apokryfy Starego Testamentu, red. R. Rubinkiewicz, Warszawa 1999 oraz P. SACCHI, Apocrifi dell'Antico Testamento, t. 5.1, Torino 199710; J. H. Charlesworth. The Old Testament Pseudepigrapha, New York 1983; A. Diez Macho. Apocrifos del Antiquo Testamento, Madrid 1984. 
Syn Człowieczy, który ma sprawiedliwość i z którym mieszka sprawiedliwość" (Henet 46, 3). Anioł - przewodnik, postać typowa dla apokaliptyki, oprowadzając wizjonera - Henocha, wyjaśnia mu, że tajemnice, które zostały wyjawione Mesjaszowi przez Boga, „służą władzy jego Mesjasza, aby był mocny i dzielny na ziemi” (Henet 52, 4). Mesjańska rzeczywistość ogranicza się więc do realizmu ziemskiego. A zatem i pojmowanie „królestwa” lokuje się w tej właśnie perspektywie. Zapewne dostrzec można tutaj bardzo eksluzywistyczne pojmowanie owej społeczności przez nią samą, gdzie ów ekskluzywizm nie wyklucza co prawda przyszłego zbawienia powszechnego, na razie jednak ogranicza je wyłącznie do własnej grupy. Stąd i Bóg rozumiany jest jako władca powszechny, choć skoncentrowany na tych, którzy określają się mianem „wybranych”. Takie rozumienie podkreśla tekst Henet 53, 6 („Następnie Sprawiedliwy i Wybrany ukaże dom swego zgromadzenia. Odtąd w imię Pana Duchów nie zaznają kłopotów”), gdzie ekscytujący jest ów „dom swego zgromadzenia”. Mogłoby tu chodzić o odrębne i alternatywne dla świątyni w Jerozolimie miejsce kultu Boga. Ponadto może też chodzić tu o aspiracje do tożsamości z prorocką grupą „Reszty Izraela”. Rola Mesjasza nie jest w tym wszystkim jasna. Wspomniany jest zaledwie w tle wydarzeń przyszłych, których głównym autorem i sprawcą ma być sam Bóg. Mesjasz może być co najwyżej znamieniem i wyróżnikiem owego czasu, ale niepodobna przypisać mu jakiejkolwiek aktywnej funkcji, poza bardzo ogólnikowym „osądzeniem” tego, co tajemne (Henet 49, 4), bądź królowaniem w owych dniach (określenie eschatologiczne): „W owych dniach Wybrany zasiądzie na swym tronie i usta jego wyjawią wszystkie tajemnice mądrości, bo Pan Duchów wyjawił mu je i go uwielbił” (Henet 51, 3). Jeśli mówi się o jakiejś jego aktywności, to w Apokalipsie Abrahama, przypisując mu zadanie sprowadzenia upokorzonych przez pogan (Apabr 31,1). Takie rozumienie eschatologii łączy się z interpretacją tekstu Ps 114, 4 w kategoriach doczesności: „W owych dniach góry będą skakać jak barany, a pagórki brykać jak jagnięta nasycone mlekiem i wszyscy staną się aniołami w niebie" (Henet 51,4). Jeśli jakoś podsumować rozumienie tego typu Mesjasza, to można określić go jako tego, który ,już jest i jeszcze będzie”, w realiach ziemskiego królestwa Izraela, personalnie obejmującego „wybranych”, którym przewodniczy „Wybrany”. Niewątpliwie jest to idealny Mesjasz, idealnie realizujący Przymierze, często bowiem Henet łączy określenie „Mesjasz” z terminem „Sprawiedliwy”, zaś w Biblii z reguły utożsamia się tych którzy wiernie trzymają się Przymierza ze „sprawiedliwymi”. Brak jest odniesień dla typowego w Starym Testamencie postrzegania Mesjasza poprzez jego funkcje pasterską i królewską, może z wyjątkiem tekstu Henet 46, 5-6, mówiącego o zdominowaniu przez Syna Człowieczego ziemskich 
królów ${ }^{15}$. Co prawda bliskie wydaje się to być chrześcijańskiemu widzeniu Jezusa Chrystusa, który już zbawił i jeszcze przyjdzie w paruzji, ale różnice są jednak wyraźne.

\section{Mesjasz - Syn Boży}

Bardzo podobne jest postrzeganie roli Mesjasza w 4 Ezdrasza (3-14: Apokalipsa Ezdrasza), piśmie które powstało już po zburzeniu świątyni w roku 70, pod koniec I wieku, w jakimś środowisku apokaliptycznym ${ }^{16}$. Postać Mesjasza nawiązuje do Dn 7, 13: „oto wiatr wynurzał z serca morza coś podobnego do człowieka” (4 Ezd 13, 3). Mowa jest o Mesjaszu, zwanym często Synem Boga (syn mój), którego rola eschatologiczna jest marginalna: „Objawi się bowiem syn mój Mesjasz z tymi, którzy są z nim...” (4 Ezd 7, 28). Jednakże ów Mesjasz z pewnością jest pojmowany jako wybitny przywódca Izraela, na wzór Mojżesza, o cechach radykalnie ludzkich, z których podstawową jest przekonanie o jego śmierci: „A po tych latach umrze mój syn Mesjasz i wszyscy, którzy mają tchnienie człowieka" (4 Ezd 7, 29). Wybawcą ludu będzie przede wszystkim sam Bóg: „Oto nadchodzą dni, kiedy Najwyższy zacznie wyzwalać tych, którzy są na ziemi” (4 Ezd 13, 29). Dopiero wówczas objawi się Mesjasz - dotychczas nieznany - którym będzie ów ,jakby człowiek", widziany uprzednio jako wychodzący z morza (por. 4 Ezd 13, 3). Jego podstawową funkcją będzie sądzenie bezbożnych według prawa. Jego rola podczas tego sądu będzie jednak bierna, czysto administracyjna, jako że punktem odniesienia jest prawo. Sąd ten dokona się wówczas, kiedy nadejdzie ,jego dzień” (4 Ezd 13, 52). Zapewne widoczne tu jest odniesienie do własnego pojmowania biblijnego „dnia Jahwe”, a motywem jego nadejścia jest następująca charakterystyka tego czasu: „Prawda bowiem daleko odstąpiła, a fałsz się przybliżył" (4 Ezd 14, 17). I dopiero w tym dniu, nie wcześniej, ów Mesjasz da się poznać tak, iż można będzie go ujrzeć. Wynika z tego, że środowisko autora 4 Ezd nie odżegnuje się od rozumienia Mesjasza jako preegzystującego Syna $\mathrm{Boga}^{17}$, ale niepodobna przyjąć, żeby było to rozumienie analogiczne do chrze-

${ }^{15}$ Bardzo marginalnie jest też obecna w apokryfach starotestamentowych idea MesjaszaSługi, wyraźnie zaledwie w syryjskiej Apokalipsie Barucha 70, 9; brak jednak tej postaci elementu cierpienia, jak u Deutero-Izajasza; wydaje się też dość odległy od pojęcia Sługi w Za 3, 8.

${ }^{16}$ Rozbieżność poglądów w tej materii jest dość duża, począwszy od kręgów lewickokapłańskich, faryzejskich, przez esseńskie, radykalnych zelotów aż po pietystyczne koła judaizmu kultywującego ludową teologię apokaliptyczną; słuszne jest jednak sądzić, że użycie imienia Ezdrasza w ramach pseudonimicznej maniery pism apokryficznych oraz podkreślenie w zakończeniu Apokalipsy Ezdrasza $(14,50)$ jego funkcji pisarza może wskazywać na ludowe środowisko kultywujące cześć dla Prawa jako naczelną swą zasadę i jednocześnie odżegnujące się od statycznego rabinizmu.

${ }^{17}$ A. Diez Macho, Apocrifos del Antiquo Testamento, Madrid 1984, t. 1, 256. 
ścijańskiego, choćby z tej racji, że idea mesjańska 4 Ezd zdaje się pozostawać w kategoriach czysto ziemskich i narodowych. Gdyby środowiskiem powstania Apokalipsy Ezdrasza (jako części 4 Ezd) był ruch zelotów, zrozumiały byłby radykalizm „owego dnia” eschatologicznego. Jako Syna Bożego prezentuje Mesjasza także Henet 105, 2: „Albowiem ja i mój syn dołączymy się do nich na zawsze na ścieżkach prawości za ich życia i będziecie zaznawać pokoju”. Niewątpliwie jest to wyrażenie tęsknej, pietystycznej i utopijnej - biorąc pod uwagę ówczesne realia historyczne - myśli o wyzwoleniu Izraela i powszechnym panowaniu Boga w ramach teokratycznego, ziemskiego królestwa, które rządzić się będzie Prawem Przymierza. Nastanie ono wówczas, kiedy objawi się metaforyczny lew, oznaczający pomazańca (Mesjasza), „którego Najwyższy zachował na koniec...” (4 Ez 12, 32).

Kraków

SYLWESTER JEDRZEJEWSKI SDB

\section{Summary}

The Messianism ideas in Judaism after the Babylon deportation

Dramatic events of year 587/586 triggered off a new way of thinking of Israelites over their history. It helped to think about resurrection not only in a traditional way - a ruler from the House of David, the King-Messiah and the Shepherd-Messiah. The lacks of political independence made people think of a new Kingdom. They were looking for a nationalist Messiah, who would realistically restore the kingdom of David and Salomon. The Son of Man, through his deep relationship with God, expressed a longing for ideal Kingdom, where God can reign. The Messiah, just and chosen by God, would represent those, who saw Israel as a great Kingdom of Israel, perfectly keeping the Law and living in peace. The Son of God, mysterious pre-existent Messiah, represents those, who yearn for a new and great leader, who is supported by almighty God and who would restore a worldly, wonderful Kingdom. 